\title{
Aspergillus Colonization and Aflatoxin Contamination in Peanut Genotypes with Resistance to Other Fungal Pathogens
}

\author{
C. Corley Holbrook, Reosearch Geneticist, USDA-ARS, Tifton, GA 31793; David M. Wilson, Professor, Department \\ of Plant Pathology, University of Georgia, Tifton 31793; Michael E. Matheron, Professor, Department of Plant \\ Pathology, University of Arizona, Yuma 85364; and William F. Anderson, Former Postdoctoral Research Associate
}

\begin{abstract}
Holbrook, C. C., Wilson, D. M., Matheron, M. E., and Anderson, W. F. 1997. Aspergillus colonization and aflatoxin contamination in peanut genotypes with resistance to other fungal pathogens. Plant Dis. 81:1429-1431.

Indirect selection tools would be valuable in the development of peanut (Arachis hypogaea) cultivars with resistance to aflatoxin contamination. The objective of this study was to determine whether resistance to other fungi could be used as an indirect selection tool for resistance to colonization of peanut by Aspergillus flavus group fungi or aflatoxin contamination. Nine peanut genotypes with resistance to late leaf spot (Cercosporidium personatum) or white mold (Sclerotium rolfsii) were evaluated for 2 years at Tifton, GA, and Yuma, AZ. Plots were subjected to late-season heat and drought stress. None of the genotypes exhibited less colonization of shells or kernels by A. flavus group fungi than cv. Florunner when tested in Georgia or Arizona. None of the genotypes showed a reduced level of aflatoxin contamination in comparison to Florunner at either location. These results indicate that the mechanisms of resistance to other fungi operating in these genotypes are not effective in providing resistance to colonization by $A$. flavus group fungi or reducing aflatoxin contamination. Therefore, resistance to these fungi cannot be used as an indirect selection tool for resistance to aflatoxin contamination.
\end{abstract}

Additional keywords: Aspergillus parasiticus, groundnut, mycotoxin

Preharvest aflatoxin contamination is one of the most serious challenges facing the U.S. peanut industry. The development of peanut (Arachis hypogaea) cultivars with reduced aflatoxin contamination when grown under heat- and drought-stressed conditions would be a valuable tool in alleviating this problem. Aflatoxin contamination is an expensive characteristic to measure and is subject to extreme variability. The development of resistant cultivars could be accelerated if an effective characteristic for indirect selection was found.

There are ongoing research programs attempting to transform peanut with antifungal genes as a possible approach to managing aflatoxin contamination in peanut. It is unknown whether there are naturally occurring antifungal genes in peanut that may be effective in reducing aflatoxin contamination.

Mehan et al. $(6,7)$ examined field resistance to Aspergillus flavus and other soilborne fungi in genotypes resistant and sus-

Corresponding author: C. C. Holbrook E-mail: nfla@tifton.cpes.peachnet.edu

Current address of W. F. Anderson: Stoneville Pedigree Seed, Box 167, Stoneville, MS 38776.

Accepted for publication 19 August 1997.

Publication no. D-1997-0929-05R

This article is in the public domain and not copyrightable. It may be freely reprinted with customary crediting of the source. The American Phytopathological Society, 1997. ceptible to in vitro seed colonization by $A$. flavus. They reported that the resistant genotypes had significantly lower levels of seed infection with A. flavus and other fungi than did genotypes reported as susceptible to in vitro colonization.

The objective of this study was to determine whether some naturally occurring antifungal genes have an effect on colonization of peanut by A. flavus or aflatoxin contamination.

\section{MATERIALS AND METHODS}

Nine peanut genotypes were selected for evaluation of Aspergillus colonization and preharvest aflatoxin contamination based on their resistance to late leaf spot (Cercosporidium personatum) (1) or white mold (Sclerotium rolfsii ) (4). Cv. Florunner was included as a susceptible check. Seeds were planted in Yuma, AZ, on 25 May 1993 and 4 May 1994 in double-row plots $(1.5 \times 1.8 \mathrm{~m})$ at 4 seeds per $30-\mathrm{cm}$ linear row. Genotypes in each trial were arranged in a randomized complete block design with 10 replications. All plants were maintained with adequate moisture, using flood irrigation.

The same genotypes were evaluated at the Coastal Plain Experiment Station Gibbs Farm in Tift County, GA. Genotypes were planted on 21 June 1993 and 26 May 1994 in single-row plots, $1.5 \mathrm{~m}$ long, at 4 seeds per $30-\mathrm{cm}$ linear row in a randomized complete block design with 10 replications. Plants were maintained with standard cultural practices and irrigation.
Inoculum of A. flavus (NRRL 3357) and A. parasiticus (NRRL 2999) was prepared by the organic-matrix method (9) and introduced into test plots to insure the presence of sufficient aflatoxin-producing fungi in the peanut pod zone. Conidia of $A$. flavus or $A$. parasiticus, each from a 10 day culture, were suspended in sterile distilled water $(10 \mathrm{ml} / 114 \mathrm{~g}$ of corn $)$ and used to inoculate sterile moisture-equilibrated $(25 \%$ moisture) cracked corn. The corn was incubated at 25 to $30^{\circ} \mathrm{C}$ for 3 days. Fungi did not sporulate during the 3-day incubation, diminishing worker's exposure to airborne conidia.

Each double-row plot in Arizona was treated with $57 \mathrm{~g}$ of corn infested with $A$. flavus and $57 \mathrm{~g}$ of corn infested with $A$. parasiticus on 26 July 1993 and 18 July 1994. Drought stress was induced by terminating flood irrigation on 17 August 1993 and 14 August 1994. Thereafter, irrigation was applied with subsurface perforated tubing $35 \mathrm{~cm}$ beneath the rows. Four hours of drip irrigation was applied when plants showed significant symptoms of drought stress (5). Pods were harvested on 14 October 1993 and 29 September 1994, dried, and sent to the Coastal Plain Experiment Station for processing.

Each single-row plot in Georgia was inoculated with $28 \mathrm{~g}$ of corn infested with A. flavus and $28 \mathrm{~g}$ of corn infested with A. parasiticus on 25 August 1993 and 3 August 1994. Drought and heat stress was induced by covering the entire test area with a mobile greenhouse (Atlas Greenhouse Systems Inc., Alapaha, GA) on 20 September 1993 and 12 September 1994. Pods were dug 15 November 1993 and 28 October 1994, hand-picked from the plant, and dried.

Seeds from undamaged pods were stored at $-20^{\circ} \mathrm{C}$ until processing to prevent postharvest accumulation of aflatoxin. Peanuts were shelled with a Penco (Peerless Engineering Co., Chula, GA) peanut sheller and ground in a household food processor for $1 \mathrm{~min}$. Aflatoxin concentration was measured on a $100-\mathrm{g}$ subsample by the immunoaffinity column fluorometer method (8). The fluorometer was calibrated from 0 to $400 \mathrm{ng} / \mathrm{ml}$. If the initial analysis indicated a concentration above 400 $\mathrm{ng} / \mathrm{ml}$, the sample extract was diluted 1:10 and reanalyzed. If the reanalyzed sample indicated a concentration above $4,000 \mathrm{ng} / \mathrm{ml}$, an additional 1:10 dilution and analysis was performed. 
Fifty pods were surface-disinfected with $0.5 \%$ sodium hypochlorite and aseptically shelled for analysis of infection by species of the A. flavus group and A. niger. Halfshells (100) and kernels (100) were placed in petri dishes containing malt extract agar containing $10 \% \mathrm{NaCl}$ by weight and incubated at $30^{\circ} \mathrm{C}$. After 7 days, the material was examined for green conidial heads of Aspergillus spp. of the A. flavus group and black conidial heads of $A$. niger to determine the percent infection.

Data were analyzed by the general linear model procedure of SAS (Cary, NC) and genotypic means were compared by Fisher's protected least significant difference (LSD). Unless otherwise stated, all differences referred to in the text were significant at $P \leq 0.05$.

\section{RESULTS AND DISCUSSION}

None of the genotypes with resistance to late leaf spot or white mold exhibited less colonization of shells or kernels by $A$. flavus group fungi than Florunner when tested in Georgia (Table 1). All these genotypes were also at least as susceptible as Florunner to colonization of shells and kernels by A. niger in tests in Georgia. Five of these genotypes were more susceptible than Florunner to colonization of shells by $A$. flavus group fungi, and one (PI 210831) was more susceptible to colonization of kernels. These results indicate that the mechanisms of resistance to other fungi operating in these genotypes are not effective in providing resistance to colonization by $A$. flavus group fungi.

The patterns observed in colonization of shells or kernels in Georgia were not observed when this material was tested in Arizona (Table 1). There were no significant genotypic differences in colonization data from Arizona. This may be due to the dif- ferences in environmental variables (temperature and humidity) between the two locations, or it may be due to a difference in fungal population dynamics between the two locations. Wilson et al. (10) observed poor survival of $A$. parasiticus in Arizona. The developing pods in the Georgia tests were challenged by a mixture of $A$. flavus and $A$. parasiticus, whereas those in the Arizona test were challenged primarily by A. flavus.

None of the genotypes examined in this study exhibited a reduced level of preharvest aflatoxin contamination compared to Florunner when tested in Georgia or Arizona (Table 2). One of the genotypes (PI 196660) exhibited significantly higher aflatoxin contamination in Arizona.

Published information on the reaction of these genotypes to Aspergillus is available

Table 2. Preharvest aflatoxin contamination in peanut genotypes with resistance to other fungi when stressed with drought in Georgia and Arizona (1993 and 1994)

\begin{tabular}{lcc}
\hline & \multicolumn{2}{c}{$\begin{array}{c}\text { Aflatoxin concentration } \\
(\mathbf{n g} / \mathbf{m l})^{\mathbf{a}}\end{array}$} \\
\cline { 2 - 3 } Genotype & Georgia & Arizona \\
\hline PI 196725 & 736 & 1,111 \\
PI 196660 & 676 & 7,012 \\
PI 203396 & 562 & 85 \\
Florunner & 365 & 186 \\
PI 210831 & 295 & 786 \\
PI 196627 & 191 & 294 \\
Southern Runner & 165 & 832 \\
PI 196768 & 157 & 559 \\
PI 215695 & 139 & 186 \\
PI 162531 & 127 & 175 \\
LSD $^{\mathrm{b}}$ (0.05) & NS & 4,253 \\
\hline
\end{tabular}

a Each value is the mean of 10 replications averaged for 2 years.

${ }^{\mathrm{b}}$ Least significant difference.

${ }^{c}$ Entry effect in analysis of variance was not significant. for only Florunner and Southern Runner. Florunner is the standard susceptible check in peanut for susceptibility to Aspergillus infection. Southern Runner has been reported to have resistance to preharvest aflatoxin contamination (3). Although Southern Runner has resistance to several fungal pathogens, the proposed mechanism of resistance to aflatoxin contamination was drought tolerance or avoidance. Anderson et al. (2) did not observe a reduction in aflatoxin contamination of Southern Runner when tested for 2 years in Arizona and 1 year in Georgia. They proposed that there may be a low level of resistance in Southern Runner; however, the resistance can be overwhelmed under certain environmental conditions. The current results support the findings of Anderson et al. (2).

Studies examining genetic differences in preharvest aflatoxin contamination are expensive to conduct and subject to large variability. It would be desirable to identify indirect selection tools. The expense and variability are much less for measuring genetic differences in resistance to leaf spot or white mold. Unfortunately, the genes for resistance to leaf spot and white mold in this set of peanut accessions were not effective in reducing colonization by A. flavus group fungi or preharvest aflatoxin contamination. Therefore, resistance to these other fungi cannot be used as an indirect selection tool for resistance to A. flavus or aflatoxin contamination.

\section{ACKNOWLEDGMENTS}

This work was supported in part by a grant from the National Peanut Foundation. We thank J. Day, B. Evans, V. Hogan, D. Mauldin, and B. Tyler for their contributions and technical support.

\section{LITERATURE CITED}

1. Anderson, W. F., Holbrook, C. C., and Brenneman, T. B. 1993. Resistance to Cercospor-

Table 1. Aspergillus colonization in kernels and shells of various peanut genotypes with resistance to other fungi when grown under drought-stressed conditions in Georgia (1993 and 1994) and Arizona (1994)

\begin{tabular}{|c|c|c|c|c|c|c|c|c|}
\hline \multirow[b]{4}{*}{ Genotype } & \multicolumn{8}{|c|}{ Aspergillus colonization (\%) } \\
\hline & \multicolumn{4}{|c|}{ Georgia } & \multicolumn{4}{|c|}{ Arizona } \\
\hline & \multicolumn{2}{|c|}{ Kernel $^{\mathbf{a}}$} & \multicolumn{2}{|c|}{ Shell $^{\mathbf{b}}$} & \multicolumn{2}{|c|}{ Kernela $^{\mathbf{a}}$} & \multicolumn{2}{|c|}{ Shell $^{b}$} \\
\hline & A. flavus & A. niger & A. flavus & A. niger & A. flavus & A. niger & A. flavus & A. niger \\
\hline PI 210831 & 28.5 & 2.3 & 61.5 & 15.5 & 17.6 & 2.3 & 51.4 & 16.3 \\
\hline PI 203396 & 23.0 & 7.5 & 52.8 & 22.0 & 20.9 & 0 & 59.0 & 29.0 \\
\hline PI 215695 & 19.7 & 5.0 & 46.5 & 10.5 & 5.4 & 0.1 & 55.0 & 15.9 \\
\hline PI 196660 & 18.5 & 1.0 & 46.4 & 7.0 & 25.6 & 1.4 & 61.9 & 14.0 \\
\hline PI 162531 & 16.3 & 10.4 & 49.2 & 25.0 & 15.0 & 0 & 70.6 & 43.4 \\
\hline PI 196768 & 15.7 & 4.5 & 42.8 & 15.1 & 1.7 & 1.0 & 40.9 & 35.9 \\
\hline PI 196627 & 11.5 & 1.3 & 32.5 & 7.9 & 16.6 & 0.8 & 58.2 & 29.2 \\
\hline Florunner & 9.5 & 5.7 & 21.8 & 12.9 & 21.8 & 0 & 50.7 & 25.1 \\
\hline Southern Runner & 6.8 & 2.7 & 28.5 & 27.4 & 1.6 & 0 & 56.6 & 17.6 \\
\hline PI 196725 & 6.0 & 0.3 & 29.3 & 6.5 & 18.4 & 0.1 & 62.4 & 21.0 \\
\hline $\operatorname{LSD}^{\mathrm{c}}(0.05)$ & 18.1 & $N S^{d}$ & 23.7 & 17.0 & NS & NS & NS & NS \\
\hline
\end{tabular}

${ }^{a}$ Each value is the mean percentage of kernels colonized, determined by plating a 100-kernel subsample from 10 replications for 2 years (Georgia) or 1 year (Arizona).

${ }^{\mathrm{b}}$ Each value is the mean percentage of half-shells colonized, determined by plating a 100-half-shell subsample from 10 replications for 2 years (Georgia) or 1 year (Arizona).

${ }^{\mathrm{c}}$ Least significant difference.

${ }^{\mathrm{d}}$ Entry effect in analysis of variance was not significant. 
idium personatum within peanut germplasm. Peanut Sci. 20:53-57.

2. Anderson, W. F., Holbrook, C. C., Wilson, D. M., and Matheron, M. E. 1995. Evaluation of preharvest aflatoxin contamination in several potentially resistant peanut genotypes. Peanut Sci. 22:29-32

3. Cole, R. J., Sobolev, V. S., and Dorner, J. W. 1993. Potentially important sources of resistance to prevention of preharvest aflatoxin contamination in peanuts. (Abstr.) Proc. Am. Peanut Res. Educ. Soc. 25:78.

4. Holbrook, C. C., Csinos, A. S., and Brenneman, T. B. 1990. Field and greenhouse techniques for evaluating peanut genotypes for resistance to white mold (Sclerotium rolfsii). (Abstr.) Proc. Am. Peanut Res. Educ. Soc. 22:55.
5. Holbrook, C. C., Matheron, M. E., Wilson, D. M., Anderson, W. F., Will, M. E., and Norden, A. J. 1994. Development of a large-scale field system for screening peanut for resistance to preharvest aflatoxin contamination. Peanut Sci. 21:20-22.

6. Mehan, V. K., McDonald, D., and Rajagopalan, K. 1987. Resistance of peanut genotypes to seed infection by Aspergillus flavus in field trials in India. Peanut Sci. 14:17-21.

7. Mehan, V. K., McDonald, D., Ramakrishna, N., and Williams, J. H. 1986. Effects of genotype and date of harvest on infection of peanut seed by Aspergillus flavus and subsequent contamination with aflatoxin. Peanut Sci. 13:46-50.

8. Trucksess, M. W., Stack, M. E., Nesheim, S., Page, S. W., Albert, R. H., Hansen, T. J., and
Donahue, K. F. 1991. Immunoaffinity column coupled with solution fluorometry or liquid chromatography postcolumn derivitization for determination of aflatoxins in corn, peanuts and peanut butter: Collaborative study. J. Assoc. Off. Anal. Chem. 74:81-88.

9. Will, M. E., Holbrook, C. C., and Wilson, D. M. 1994. Evaluation of field inoculation techniques for screening peanut genotypes for reaction to preharvest $A$. flavus group infection and aflatoxin contamination. Peanut Sci. 21 122-125.

10. Wilson, D. M., Holbrook, C. C., and Matheron, M. E. 1996. Aspergillus flavus and A. parasiticus used as peanut plot inoculum to study preharvest aflatoxin contamination. (Abstr.) Proc. Am. Peanut Res. Educ. Soc. 28:30. 